\title{
Gambaran risiko penularan flu burung pada pedagang burung di Kota Pagar Alam melalui prinsip biosekuriti
}

\author{
Tetty Barunawati Siagian*, Edo Saputra Pratama
}

Program Studi Paramedik Veteriner, Sekolah Vokasi, Institut Pertanian Bogor, Bogor

\begin{abstract}
ABSTRAK: Flu burung disebabkan oleh virus avian influenza yang bersifat zoonosis atau dapat menular dari hewan ke manusia atau sebaliknya. Penelitian ini bertujuan untuk menggambaran risiko penularan flu burung pada pedagang burung yang ada di kota Pagar Alam Sumatera Selatan berdasarkan prinsip biosekuriti. Penelitian studi lapang cross-sectional dengan kuesioner terstruktur yang memiliki keterkaitan erat dengan pokok-pokok permasalahaan dan melakukan observasi terhadap praktik biosekuriti kepada 13 responden. Hasil kusioner menunjukkan pedagang belum memahami dan belum menerapkan prinsip biosekuriti dalam tokonya. Prinsip biosekuriti yang telah dilakukan berupa kegiatan sanitasi sebagai bentuk kebiasaan pedagang membersihkan kandang burung setiap hari, namun kegiatan ini dilaksanakan tidak maksimal. Prinsip biosekuriti lain seperti isolasi dan kontrol lalu lintas belum dilakukan dengan baik. Kesadaran untuk memvaksinasi burung yang dijual juga belum ada sehingga resiko penularan flu burung berpotensi sangat tinggi bagi pedagang atau ke sesama burung di toko burung.
\end{abstract}

Kata kunci:

flu burung, biosekuriti, sanitasi, isolasi

\section{- PENDAHULUAN}

Hewan peliharaan menjadi human substitute sebagai teman bahkan keluarga (Redaksi Agromedia 2008). Perkembangan pencinta hewan peliharaan di Kota Pagar Alam semakin meningkat, termasuk burung peliharaan. Minat tersebut ditandai dengan munculnya toko-toko atau kios yang menjual burung. Flu burung merupakan salah satu penyakit yang dapat menular dari unggas ke manusia. Kasus flu burung masih menjadi perhatian dunia karena virus terus bermutasi dan berpotensi pandemik (Kemenkes RI 2013). Pencegahan flu burung dapat melalui program biosekuriti yaitu sanitasi, isolasi dan pembatasan lalu lintas. Biosekuriti merupakan upaya mengurangi penyebaran penyakit dengan menghalangi kontak antara hewan dan mikroorganisme (Jeffrey 2006). Berdasarkan hal tersebut maka tulisan ini bertujuan untuk memberikan gambaran risiko penularan flu burung pada pedagang burung di Kota Pagar Alam Sumatera Selatan berdasarkan prinsip biosekuriti..

\section{- METODE}

Objek kajian sebanyak 13 toko burung di Kota Pagar Alam, Sumatera Selatan. Data hasil studi lapang cross-sectional dengan wawancara terhadap responden terpilih menggunakan kuesioner. Kuesioner diarahkan pada pokok permasalahan dan tujuan yang berkaitan erat.

\section{- HASIL}

Hasil kuesioner dari 13 responden toko burung berjenis kelamin laki-laki 12 pedagang $(92,3 \%)$ dan hanya 1 orang perempuan (7,7\%). Mayoritas pedagang berusia 25-45 tahun ada
8 pedagang $(61,5 \%),>45$ tahun ada 4 orang $(30,8 \%)$ dan $<$ 25 tahun hanya 1 orang $(7,7 \%)$.

Jenis burung yang dijual 100\% adalah burung kicau dan burung hias. Pedagang juga menjual burung konsumsi yaitu 7 orang $(58,3 \%)$. Burung yang dijual berasal dari peternakan dan dari tangkapan liar dengan persentase sama yaitu $69,2 \%$, 7 responden $(53,8 \%)$ memperoleh burung dari pasar burung lain di luar kota Pagar Alam dan 5 responden (38,5\%) memperoleh burung dari pedagang eceran antar pedagang atau dari masyarakat yang menjual burung peliharaan, serta 5 responden $(38,35 \%)$ memperoleh burung yang dijual dari luar pulau Sumatera.

Semua pedagang burung telah menerapkan sanitasi dengan membersihkan area dan kandang burung. Responden mencuci kandang burung menggunakan air dan deterjen. Hanya 3 orang $(23,1 \%)$ yang menambahkan desinfektan saat membersihkan kandang burung. Mayoritas responden yaitu 10 orang $(76,9 \%)$ mencuci kandang burung hampir setiap hari. Hanya 1 orang membersihkan kandang beberapa kali dalam seminggu dan 2 orang membersihkan kandang secara tidak teratur. Praktik higiene personal hanya 4 orang $(30,8 \%)$ yang mencuci tangan menggunakan deterjen dan 9 orang hanya menggunakan air bersih. Semua responden tidak menggunakan pakaian khusus saat bekerja dalam menangani burung di kios. 
Mayoritas pedagang yaitu 8 orang $(61,5 \%)$ membersihkan kandang burung yang baru datang terlebih dahulu. Pedagang sebanyak 11 orang $(84,6 \%)$ tidak melakukan apapun terhadap burung yang sakit, hanya 2 responden $(15,4 \%)$ melakukan pengobatan ketika burung terlihat sakit dan memisahkannya pada kandang khusus untuk burung yang memiliki harga jual tinggi. Selanjutnya 10 pedagang (76,9\%) membuang burung yang mati ke tempat sampah dan masingmasing 1 orang $(7,7 \%)$ pedagang burung mengubur, membakar dan membuang burung yang mati ke selokan atau sungai. Semua responden (100\%) tidak ada yang memvaksin burung yang dijual.

Responden pernah meminjam kandang dari pedagang lain sebanyak 2 orang $(15,4 \%)$ dengan tidak membersihkan dahulu kandang pinjaman. Responden yang pernah mendapat titipan burung dari pedagang lain langsung dicampur dan berdekatan satu ruang dengan kandang burung lainnya ada 2 responden $(15,4 \%)$. Kehadiran burung liar masuk ke area kandang dengan mudah terjadi diseluruh toko burung di kota Pagar Alam yang merupakan toko terbuka. Lokasi berjualan pedagang mayoritas berada di pinggir jalan sehingga kehadiran burung liar sulit untuk dicegah. Seluruh kios pedagang tempat jual beli burung bisa bebas dimasuki orang lain.

\section{- PEMBAHASAN}

Virus flu burung subtipe H5N1 dapat ditemukan secara alami pada burung liar dan dapat menyerang unggas, burung dan hewan lain (CDC 2014). Perpindahan unggas atau burung dari satu daerah ke daerah lain dapat memunculkan penyakit baru di daerah yang semula belum ada (Martindah et al. 2006). Karakteristik yang paling menonjol dari bibit penyakit adalah menyukai tempat kotor dan lembab sehingga menyebabkan mikroorganisme penyebab penyakit dapat berkembang dengan cepat (Abidin 2003). Sanitasi harus dilaksanakan secara teratur untuk memperoleh lingkungan yang bersih, higienis, dan sehat (Sudarmono 2003). Unggas mati, bulu, sisa kotoran, sisa pakan dan alas kandang seharusnya dibakar dan dikuburkan dalam pengawasan petugas berwenang (Deptan RI 2007).

Menjaga kebersihan kandang merupakan salah satu langkah untuk mengurangi populasi bibit penyakit dalam sistem biosekuriti. Kondisi kesehatan burung baru dapat berpotensi menularkan penyakit yang dibawanya. Pemisahan burung atau isolasi harus dilakukan untuk memastikan burung benar-benar sehat. Menurut Hadi (2001), agen penyakit dapat terbawa melalui debu, bulu-bulu atau sayap dan kotoran (manure) pada alat dan sarana lain seperti truk, kandang, dan tempat telur. Pengendalian lalu lintas diupayakan untuk menapis orang, alat, barang dan hewan lain, agar kegiatan lalu lintas tidak membawa patogen masuk ke dalam farm (Johari 2004).
Vaksinasi merupakan proses pengebalan tubuh dengan melemahkan mikroorganisme yang menyebabkan penyakit (Saputro et al. 2014). Vaksin dapat diberikan dengan cara tetes mata, tetes hidung, disuntikkan pada urat daging, dicampurkan dengan pakan, air minum, dan disemprotkan (Ayu et al. 2013). Tindakan vaksinasi untuk mencegah penularan flu burung pada burung tidak dilakukan sehingga meningkatkan risiko penularan.

\section{SIMPULAN}

Gambaran resiko penularan flu burung sangat tinggi pada pedagang burung di Kota Pagar Alam karena belum memahami dan belum menerapkan prinsip biosekuriti dengan baik dalam tokonya.

\section{— INFORMASI PENULIS}

Penulis Korespondensi

*TBS: tettyvirus@gmail.com

Program Studi Paramedik Veteriner, Sekolah Vokasi, Institut Pertanian Bogor, Kampus IPB Cilibende Jl Kumbang No. 14 Bogor 16151, Jawa Barat, INDONESIA

\section{- UCAPAN TERIMA KASIH}

Toko-Toko Pedagang Burung di Kota Pagar Alam, Pagar Alam

\section{- PUSTAKA ACUAN}

Abidin Z. 2003. Meningkatkan Produktivitas Ayam Ras Petelur. Jakarta (ID): PT. Agromedia Pustaka

Ayu G, Kencana Y, Virologi L, Hewan FK, Udayana U. 2013. Penentuan Kandungan Virus Vaksin Newcastle Disease Dari Dua Poultry Shops Yang Berbeda Pada Kultur Sel Primer Fibroblast Embrio Ayam. 5(2): 61-69

Centers for Disease Control and Prevention. 2014. Information on Avian Influenza. [20/08/2020]. http://www.cdc.gov/flu/avianfl

Depkes RI. 2013. Buku Saku Flu Burung. Jakarta (ID): Departemen Kesehatan Republik Indonesia

Deptan RI. 2007. Pedoman Umum Restrukturisasi Perunggasan Melalui Penataan Pemeliharaan Unggas di Pemukiman. Jakarta (ID): Departemen Pertanian Republik Indonesia

Hadi IK. 2001. Biosekuritas Farm Pembibitan Ayam (1). Poultry Indonesia. Desember 260: 88-90.

Jeffrey JS. 2006. Biosecurity for poultry flocks. Poultry fact sheet 1(26). [22/10/2020]. http://www.vmtrc.ucdavis.edu.html

Johari S. 2004. Sukses Beternak Ayam Ras Petelur. Jakarta (ID): PT. Agromedia Pustaka.

Martindah E, Priyanti A, Nurhayanti IS. 2006. Kajian pengendalian kebijakan pengendalian penyakit avian influenza di lapang. Prosiding Lokakarya Nasional Hasil Teknologi dalam Mendukung Usaha Ternak Berdaya Saing. Bogor, Indonesia. Bogor (ID): Puslitbang Peternakan. hlm 168-175.

Redaksi Agromedia. 2008. Buku Pintar Merawat Hewan Kesayangan. Jakarta (ID): PT Agromedia Pustaka. hlm 3-5.

Saputro B, Edy SP, Kurtini T. 2014. Pengaruh Cara Pemberian Vaksin ND Live Pada Broiler terhadap Titer Antibodi, Jumlah Sel Darah Merah dan Sel Darah Putih. Jurnal Ilmiah Peternakan 2(3): 43-48

Sudarmono. 2003. Pedoman Pemeliharaan Ayam Ras Petelur. Yogyakarta (ID): Kanisius. 